\title{
Frequency of Group A Beta-Hemolytic Streptococcal Angina in Children in the Department of Pediatrics of Donka National Hospital
}

\begin{abstract}
Mamadou Moustapha Diop', Aissata Barry', Emmanuel Camara1, Mohamed Lamine Diallo², M'mah Aminata Bangoura3 , Hasmiou Dia4, Saliou Bella Diallo1, Mamadou Aliou Doukouré1, Moustapha Kouyaté1, Narcisse Viani Gateu Tadjom¹, Mamadou Pathé Diallo4
\end{abstract}

${ }^{1}$ Pediatrics Department, Donka National Hospital, Conakry, Republic of Guinea

${ }^{2}$ Paediatric Medical Emergency, Donka National Hospital, Conakry, Republic of Guinea

${ }^{3}$ Institute of Nutrition and Child Health, Conakry, Republic of Guinea

${ }^{4}$ Paediatrics Department Ignace Deen National Hospital, Conakry, Republic of Guinea

${ }^{5}$ Medical Centre and Health Counselling, Conakry, Guinea

Email: docteumama@gmail.com

How to cite this paper: Diop, M.M., Barry, A., Camara, E., Diallo, M.L., Bangoura, M.A., Dia, H., Diallo, S.B., Doukouré, M.A., Kouyaté, M., Tadjom, N.V.G. and Diallo, M.P. (2020) Frequency of Group A Beta-Hemolytic Streptococcal Angina in Children in the Department of Pediatrics of Donka National Hospital. Open Journal of Pediatrics, 10, 610-616.

https://doi.org/10.4236/ojped.2020.104062

Received: October 9, 2020

Accepted: November 17, 2020

Published: November 20, 2020

Copyright $\odot 2020$ by author(s) and Scientific Research Publishing Inc. This work is licensed under the Creative Commons Attribution International License (CC BY 4.0).

http://creativecommons.org/licenses/by/4.0/ (c) (i) Open Access

\begin{abstract}
Background: Angina is a common paediatric condition. It has certain peculiarities in children, particularly with regard to the frequency of bacterial germs and the use of diagnostic tests. The aim of this study was to determine the place of the rapid diagnostic test in the management of group A beta-hemolytic streptococcal angina in children in the paediatric ward at Donka National Hospital. Methods: This was a prospective descriptive study lasting 6 months from 1st February to 31st July 2019 concerning children aged between 3 and 15 years old who were diagnosed with angina. Epidemiological, clinical, para-clinical and therapeutic variables were studied. Results: Out of 1494 registered children, we collected 116 cases of angina (7.76\%). Out of 52 patients who benefited from the rapid diagnostic test, we recorded 13 cases of angina due to group A beta-hemolytic strptococcus. The male sex was the most dominant with 31 cases $(59.69 \%)$ and a G/F sex ratio of 1.47. The age group most affected was between 3 and 5 years old (50\%). The average age of our patients was 4.8 years with extremes of 3 and 14 years. Clinical manifestations were dominated by fever and dysphagia (100\%) followed by odynophagia (11.79\%). We recorded 13 cases of streptococcal angina (25\%). Conclusion: The factors that influence it are multiple, dominated by community life, passive smoking and allergies. The use of RDTs in these
\end{abstract}


young children would help in the diagnosis of acute group A beta hemolytic streptococcal angina and rational antibiotic prescription.

\section{Keywords}

Angina, Frequency, Clinic, Treatment, Pediatrics, Donka

\section{Introduction}

Angina is an acute inflammation, usually caused by infectious of the palatine amygdala. It is a diagnosis frequently made in our common practice [1]. There are some peculiarities in children with regard to the prevalence and frequency of bacterial germs and the use of diagnostic tests [2].

The etiology is predominantly viral. When the origin is bacterial, the group A haemolytic Streptococcus $\beta$ is the most frequently documented germ [3]. For both children and adults, the use of RDTs was the strategy of the most efficient way of identifying and treating patients with group A beta-hemolytic streptococcal angina beta [4]. Depending on age, $50 \%$ to $90 \%$ of them are presumed to have a viral cause and about 20\% (all of which are ages combined) of bacterial cause [5].

According to the French ENT society (SFORL), other bacterial anginas are exceptional and are mainly linked to Corynebacterium diphteriae, which has practically disappeared in France since compulsory vaccination, Neisseria gonorrhoeae or anaerobic germs for necrotizing angina [6].

Group A beta-hemolytic streptococcal angina is benign and usually progresses favourably in 3 to 7 days, even without treatment. However, their treatment is dominated by over-prescription of antibiotics, which is responsible for the resistance of the bacteria and the disruption of the immune maturation process in children [7].

Group A beta hemolytic streptococcus is the 9th leading cause of fatal infections worldwide. It is responsible for 1.8 million severe infections and 517,000 deaths per year [4]. In the United States of America, according to some estimates, there are approximately 30 million of group A beta-hemolytic streptococcus infections per year, including 1000 deaths from invasive diseases [8]. Group A Streptococcus is present in $20 \%-40 \%$ of childhood pharyngitis [4]. A study published in 2010 by Mezghani M. et al. in Tunisia on acute angina in children reported a prevalence of $32.9 \%$ in children aged 4 to 8 years [9].

Another study carried out in Cameroon by Bola S. et al. on the diagnostic value of group A beta haemolytic streptococcal TDR in the diagnosis of acute angina in the ENT department of the Yaoundé University Hospital found a prevalence of $44.33 \%$ of streptococcal angina in patients aged 3 to 15 years [10].

The general objective of this study was the frequency of streptococcal angina and the epidemiological and clinical profile of patients in the paediatric ward of Donka National Hospital. 


\section{Methods}

It was a prospective study of a descriptive type for a period of 6 months from February 1st to July 31st 2019. This study was carried out in the paediatric ward of the Donka National Hospital (Conakry). The study population consisted of all patients aged between 3 and 15 years old who were diagnosed with angina.

We included in the study all children aged 0 - 15 years with a diagnosis of angina. We have not included patients who have not been diagnosed with angina. The rapid dignostic test was carried out to confirm streptococcal angina

We studied the data: epidemiological (age, sex, favouring factors, season), clinical and paraclinical (reasons for consultation, signs on clinical examination, associated pathologies, results of the RDT), therapeutic (treatment received).

Data was collected on a pre-established and validated survey form. The data were entered and processed using the Epi info 7.2 software and then presented in the form of results using the Word and Excel software of the 2010 office pack.

A protocol was drawn up and validated before the start of the surveys. The authorisation of the heads of the paediatric service was obtained before the start of the investigations. The informed consent of the parents was obtained for this work. The anonymity and confidentiality of the information collected were preserved 2.1.

\section{Results}

Out of a total of 1494 patients registered in the paediatrics department of Donka National Hospital, we have documented 116 cases of angina, a frequency of $7.76 \%$. Out of 52 patients who benefited from the rapid diagnostic test, we recorded 13 cases of angina due to group A beta-hemolytic strptococcus.

The age group most affected was less than 5 years old 27 cases (50\%) Male dominated with 31 cases or $59.62 \%$ (Table 1 ).

We found 31 children living in the community (59.62\%), 18 (34.62\%) cases of exposure to passive smoking by parents and 3 cases of tobacco allergies (5.76\%).

The buccopharyngoscopy allowed us to identify $33 \%$ of erythematous angina and $67 \%$ of erythematopultaceous angina. The most frequent reason for consultation was fever and dysphagia in $100 \%$ of the cases. There was odinophagy in 21 patients $(40.38 \%)$, reflex otalgia in 9 patients (17.3\%), rhinorrhea in 17 patients (32.69\%).

During this study, the Rapid Diagnostic Test (RDT) for streptococcal angina was carried out systematically. In the 52 patients with angina however it was negative in 39 patients, i.e. $75 \%$, and positive in 13 cases, i.e. $25 \%$.

The most frequent pathologies associated with angina were malaria 32 cases (51.61\%) and rhinopharyngitis 17 cases (27.42\%) (Table 2).

10 of our patients have had at least 2 diagnoses associated with streptococcal angina. 
Table 1. Socio-demographic characteristics of the 52 patients diagnosed with angina having benefited from the rapid diagnostic test for group A beta hemolytic streptococcus.

\begin{tabular}{ccc}
\hline Socio-demographic characteristics & Number & Percentage \\
\hline $\begin{array}{c}\text { Age range in years } \\
\text { less than } 5 \text { years }\end{array}$ & 26 & 50 \\
$6-9$ & 15 & 28.85 \\
$10-14$ & 11 & 21.15 \\
Average age $=4.8$ years Extremes $=3$ months and 14 years & \\
Sex & & \\
Male & 31 & 59.62 \\
Female & 21 & 40.38 \\
& & \\
Season & Sex-ratio M/F $=1.47$ & 61.54 \\
Rainy season & 32 \\
Dry & 20 & 38.46 \\
\hline
\end{tabular}

Table 2. Frequency of pathologies associated with angina for the 52 patients diagnosed with angina.

\begin{tabular}{ccc}
\hline Associated pathologies & Number & Percentage \\
\hline Malaria & 32 & 51.61 \\
Rhinopharyngitis & 17 & 27.42 \\
Gastroenteritis & 8 & 12.91 \\
Broncho-pneumopathy & 5 & 8.06 \\
\hline
\end{tabular}

\section{Discussion}

During the course of our study, out of 52 patients who benefited from the rapid diagnostic test, we recorded 13 cases of angina due to group A beta-hemolytic strptococcus.

In France, Nicholas $\mathrm{N}$ in 2018, in a study on the prevalence of group A beta haemolytic streptococcus in children, reported a frequency of 3.43\% [9]. Chobli $\mathrm{M}$ et al. in Benin in their study on the management of acute angina at the CNHU in Cotonou, found a frequency of $7.53 \%$ of angina in children [11]. Njifou Njimah et al. in their study at Cmeroun found a $45 \%$ frequency of angina due to group A beta hemolytic streptococcus [12].

Our results show that angina is one of the most frequent conditions in paediatric consultations. It constitutes a particular nosological entity especially in children. Viral or bacterial infection of the lymphoid tissues is beneficial in children with a maturing immune system. Most angina, $60 \%-80 \%$ are caused by viruses [13]. The usual cause of Pharyngotonsillitis are viruses, but group A Beta hemolytic streptococci is the most common bacterial cause, being responsible for $15 \%-30 \%$ of cases in children and $5 \%-10 \%$ of cases in adults [14]. These 
complications (acute rheumatic fever, rheumatic heart disease) are sometimes lethal without better care. The group A Streptococcus $\beta$-hemolytic is responsible for $20 \%$ of angina at all ages and $25 \%-40 \%$ in children [15].

Children in the less than 5 years group were the most affected, with a rate of $50 \%$, followed by those aged 6 - 9 (Table 1 ). The average age was 4.8 years with the extremes of 3 months and 14 years. Mezghani S et al. in 2010 in Tunisia observed a frequency of $32.9 \%$ in the 4 - 8 age group [9].

The search for bacterial aetiology through the systematisation of the rapid diagnostic test is essential for etiological research. This etiological research is necessary for a better management of angina in children.

In our study, we found a male predominance of $59.62 \%$ against $40.38 \%$ of the female sex with a G/F sex ratio of 1.47 (Table 1)

In Cameroon, in 2016, BOLA SIAFA et al. in a study carried out at the ENT service of the Yaoundé University Hospital revealed a female predominance of 62.9\% [10]. Mezghani S. et al. in 2010 in Tunisia found a male predominance of $54.37 \%$ compared to $45.63 \%$ of the female sex [9].

This predominance of the male sex is only by chance, because the role of sex seems insignificant in the pathogenesis of angina.

Angina can occur at any time of the year. However, a peak in the incidence of angina has been observed during the winter season. We recruited $61.54 \%$ of the patients during the winter season compared to $38.46 \%$ during the dry season.

Mezghani M et al. in Tunisia in 2010 have a peak in the frequency of angina cases in early summer (Jun and July) and another peak in the cold season from October to January. The highest frequencies of isolation of group A streptococcus were observed in October and November [9]. These results can be explained by the fact that in the rainy season, our environment is not only unhealthy, a factor that encourages the proliferation of micro-organisms, but also there is a decrease in the body's means of defence with the recrudescence of viruses in the upper respiratory tract.

The clinical manifestations of angina are rich and varied. They are dominated by a symptomatic triad: fever, dysphagia and odynophagia. Fever and dysphagia were found in all our patients (100\%); as for odynophagia, we record5ed a frequency of $11.79 \%$.

These symptoms are linked to irritation of the thermal regulation centre and vascular vasodilation with increased capillary permeability responsible for hypertrophy of the palatine tonsils, leading to pain on swallowing.

During our study period we found $59.62 \%$ of children living in the community and $34.62 \%$ of cases of exposure to passive smoking by parents.

Our results could be explained by the fact that the germs responsible for angina are transmitted by air. This is why children living in schools with overcrowded classrooms or in crowded families with the notion of intoxication linked to passive smoking are the most vulnerable.

These results confirm the hypothesis that most group A beta hemolytic streptococcal angina is erythematopultaceous. 
The TDR was performed routinely in all patients who met the inclusion criteria. However, the TDR was negative in 39 patients (75\%) and positive in 13 (25\%). These different results demonstrate the relevance of the systematisation of the TDR in the management of angina, of which $70 \%-90 \%$ are of viral origin according to the data in the literature [16]. In addition to the economic advantages of the TDR, it avoids disturbance of the bacterial flora and the mutation of common germs towards antibiotic resistance.

Malaria and rhinopharyngitis were the most associated with angina during our study period with frequencies of $51.61 \%$ and $27.42 \%$ respectively. This is due to the fact that Guinea is a malaria endemic country, therefore malaria is the leading cause of morbidity and mortality in health facilities.

Therapeutically, patient management has been guided by the results of biological examinations and the pathologies associated with angina. Thus, in the 13 patients with a positive RDT, all of them received antibiotic therapy combined with symptomatic treatment; 9 were treated with antimalarial drugs and 6 with nasal decongestants. During our study, none of our patients on treatment progressed to a complication.

\section{Conclusions}

Angina is one of the most common paediatric conditions in the paediatric ward of Donka National Hospital, affecting mostly children between the ages of 3 and 5.

The factors that influence it are multiple, dominated by life in the community, passive smoking and allergies. The clinical examination is not sufficiently discriminating, so para-clinical tests are essential. The use of RDTs in these young children would help in the diagnosis of acute SBHA angina and the rational prescription of antibiotics.

\section{Conflicts of Interest}

The authors do not declare a conflict of interest.

\section{References}

[1] Timbo, S.K., Keita, M.A., Togola, F.-K., et al. (2006) Aspects Epidemiologiques de l'angine a Bamko. Mali Médical, T XXI N 4 .

[2] Carapetis, J.R., Steer, A.C., et al. (2005) The Global Burden of Group A Streptococcal Disease. The Lancet Infectious Diseases, 5, 685-694. https://doi.org/10.1016/S1473-3099(05)70267-X

[3] Cohen, J.F., Chalumeau, M., Levy, C., Bidet, P., Thollot, F., et al. (2012) Spectrum and Inoculum Size Effect of a Rapid Antigen Detection Test for Group A Streptococcus in Children with Pharyngitis. PLOS ONE, 7, e39085.

https://doi.org/10.1371/journal.pone.0039085

[4] Raobijoana, H. (2014) Infections respiratoires aigües hautes en milieu pédiatrique à Antananarivo. Médecine d'Afrique Noire, 47, 5.

[5] Chadmi, F., Schlatter, J., Mounkassa, B., Ovetchkine, P. and Vermerie, N. (2004) 
Tests de diagnostic rapide dans la prise en charge des angines à streptocoques bêta hémolytiques du groupe A. Ann Biol Clin (Paris), 62, 573-577.

[6] Jahidi, M. (2014) Les complications des angines: Archives UPR d'ORL Rabat, Maroc. 4.

[7] American Academy, of Pediatrics (2009) Red Book: Report of the Committee on Infectious Diseases. 28th Edition. https://redbook.solutions.aap.org/DocumentLibrary/RB2009.pdf

[8] American Academy of Pediatrics. (2009) Red Book: Report of the Committee on Infectious Diseases 28th ed. [Internet]. https://redbook.solutions.aap.org/DocumentLibrary/RB2009.pdf

[9] Mezghani Maalej, S., Rekik, M., Boudaouara, M., Jardak, N., Turki, S., Arous, R., Hammami, A., et al. (2010) Les angines aiguës de l'enfant dans la région de Sfax (Tunisie): Epidémiologie et intérêt du test de diagnostic rapide. Médecine et Maladies Infectieuses, 40, 226-231. https://doi.org/10.1016/j.medmal.2009.10.016

[10] Siafa, B., Djomou, F., et al. (2016) Valeur diagnostic du TDR a streptocoque béta hémolytique du groupe A dans le diagnostic des Angines aigues au service d'ORL du CHU de Yaoundé, Cameroun. 2-4.

[11] Chobli, M., Yehouessi-Vignikin, et al. (2012) Prise en charge des angines de l'enfant en ORL au CNHU de Cotonou. Revue Africaine d'Anesthésiologie et de Médecine d Urgence, 17, 17. http://www.saranf.net/Prise-en-charge-des-angines-de-l.html

[12] Njifou Njimah, A., Zounon, D.S., Ngaba, G.P., et al. (2020) Les Angines Bactériennes à Mbouda: Aspects Cliniques et Thérapeutiques. Health Sciences and Disease, 21, 72-75. http://www.hsd-fmsb.org

[13] Ayache, D., Foulquier, S., Cohen, M. and Elbaz, P. (1997) Angines aiguës. EMC ORL Elsevier SAS, 20-500-A-10.

[14] (2005) Brook I. Brief Report a Pooled Comparison of Cefdinir and Penicillin in the Treatment of Group A Beta-Hemolytic Streptococcal Pharyngotonsillitis. 3-10.

[15] Wainsten, J.P. (2009) Larousse medical. 5th Edition, Larousse, Paris, 52.

[16] Berthélémy, S. (2016) Conseils à un patient souffrant d'une angine. Actualités Pharmaceutiques, 55, 35-38. https://doi.org/10.1016/j.actpha.2016.01.007 